九州大学学術情報リポジトリ

Kyushu University Institutional Repository

\title{
Comparison of nutritional composition of premature, mature and de-hulled barley in Korea
}

Gan, Lu-Jing

College of Agricultural and Life Sciences, Chungnam National University

Wang, Xiang-Yu

College of Agricultural and Life Sciences, Chungnam National University

Yang, Dan

College of Agricultural and Life Sciences, Chungnam National University

Shin, Jung-Ah

College of Agricultural and Life Sciences, Chungnam National University

他

https://doi.org/10.5109/1526306

出版情報：九州大学大学院農学研究院紀要. 60 (1)，pp.57-63，2015-02-27. Faculty of Agriculture， Kyushu University

バージョン :

権利関係 : 


\title{
Comparison of nutritional composition of premature, mature and de-hulled barley in Korea
}

\section{Lu-Jing GAN ${ }^{1}$, Xiang-Yu WANG ${ }^{1}$, Dan YANG ${ }^{1}$, Jung-Ah SHIN ${ }^{1}$, Ki-Teak LEE ${ }^{1}$, Jeung- Hee LEE ${ }^{2}$, Takeo YAMAKAWA* and Jin-Woong $\mathrm{CHO}^{1 *}$}

\author{
Laboratory of Plant Nutrition, Division of Molecular Biosciences, Department of Biosciences \& Biotechnology, Faculty of Agriculture, \\ Kyushu University, \\ 6-10-1 Hakozaki, Fukuoka 812-8581, Japan \\ (Received October 27, 2014 and accepted November 14, 2014)
}

\begin{abstract}
So far, there are lots of paper reported the nutritional composition of mature barley and de-hulled barley, but little research on premature barley. For the purpose of exploring nutritional potential of premature barley, we analyzed the nutritional status of premature green, mature yellow, and de-hulled barley grown in the Jeollabuk-Do Agricultural Research \& Extension Services (Iksan, Korea). Compared to de-hulled and mature barley, premature barley contained higher amounts of lysine (41.46 $\mathrm{mg} \mathrm{g}^{-1}$ protein), total essential

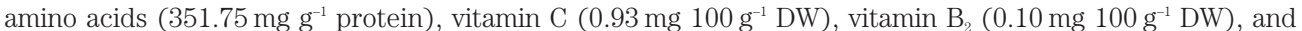

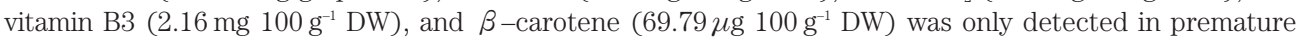
barley. Statistically higher quantities of $\mathrm{Na}$ and $\mathrm{K}$ were present in premature barley compared to the other two grain-types $(\mathrm{P} \leq 0.05)$, whereas mature barley contained the highest amount of $\mathrm{P}$ and $\mathrm{Fe}(\mathrm{P} \leq 0.05)$. All three grain-types contained similar levels of $\mathrm{Ca}$ and $\mathrm{Cu}$. Mature barley contained the highest betaine and choline (49.44 mg $100 \mathrm{~g}^{-1} \mathrm{DW}$ and $34.61 \mathrm{mg} 100 \mathrm{~g}^{-1} \mathrm{DW}$, respectively). The results indicate that premature barley is nutritionally superior to de-hulled barley.
\end{abstract}

Key words: betaine, choline, essential amino acids, premature barley

Abbreviations: ${ }^{1} \mathrm{H}$ NMR; ${ }^{1} \mathrm{H}$ nuclear magnetic resonance, GC; gas chromatography, HPLC; high performance liquid layer chromatography, IPC-AES; inductively coupled plasma atomic emission spectroscopy.

\section{INTRODUCTION}

Since ancient times, barley (Hordeum vulgare L.) has been an important cereal grain, primarily used as animal feed and for malting processes. However, the nutritional value of barley has recently been shown to be an important human food resource. Barley contains considerable levels of dietary fiber that contributes toward reducing coronary heart disease and diabetes (Huth et al., 2000; Knutsen and Holtekjølen, 2007). In particular, the beneficial health effect of $\beta$-glucans in lowering blood cholesterol levels has widely been recognized (Behall et al., 2004). Furthermore, barley provides several types of antioxidants, primarily tocopherols and other polyphenol compounds (Petti and Scully, 2009).

Because barley grains have hard hulls, these are usually removed, along with small amounts of bran, germ, and endosperm. Furthermore, after de-hulling, the remaining hull, bran, germ, and part of the endosperm are often removed during the subsequent pearling process (Baik and Ullrich, 2008). Such de-hulled or pearled barley is usually used in breakfast cereals or added to various food products, such as stews, soups, and breads. In Korea, de-hulled barley grains are usually used in food products. However, the de-hulling process causes other

\footnotetext{
College of Agricultural and Life Sciences, Chungnam National University, Daejeon, Korea

${ }^{2}$ Department of Food Nutrition, Daegu University, Daegu, Korea

* Joint Corresponding author (E-mail: yamakawa@kyushu-u. ac.jp)

1*Joint Corresponding author (E-mail: jwcho@cnu.ac.kr)
}

nutritive compounds, such as fiber and phenol, lost from the grains. For instance, whole barley grain contains $11 \%$ to $34 \%$ total dietary fiber, of which $3 \%$ to $20 \%$ is soluble dietary fiber. In comparison, de-hulled barley grain generally contains $11 \%$ to $20 \%$ total dietary fiber and $3 \%$ to $10 \%$ soluble dietary fiber (Baik and Ullrich, 2008). Furthermore, Panfili et al. (2008) reported that $\alpha$ - and $\beta$-tocopherol contents of barley pearling by-products were about seven and five-folds higher than the hulled grain, and the pearled kernel contained $4.82 \% \beta$-glucans. These results indicate that the pearling process dramatically reduced the nutritive values of barley.

Because premature barley grain has a soft pericarp, and hence softer texture than mature grain, the pearling process may not be required. Yang et al. (2012) reported that premature green wheat had significantly higher content of dietary fiber, Vitamin C, $\beta$-carotene than mature yellow wheat, indicated that premature green wheat has potential for the human diet because of its desirable nutritional value. To date, research has primarily focused on the biochemical changes of barley during grain development, few comparison has been studied on the nutritional compounds between premature barley and matured barley. In this study, in order to identify the grain type with the highest nutritional value, we compared the relative content of various compounds such as sugars, protein, dietary fiber, amino acids, vitamins, minerals, phytosterols, and fatty acids-found in premature-green barley (premature barley), mature-yellow barley (mature barley), and de-hulled barley grown in Korea. 


\section{MATERIALS AND METHODS}

\section{Plant materials and collection}

The barley grains samples were produced by the variety of barley (Hordeum distichum L. cv. Pungsanchalssalbori) grown in the Jeollabuk-Do Agricultural Research \& Extension Services (Iksan, Korea). Premature barleys were harvested on May $13^{\text {th }}$, 2010, which is 20 days after heading date (April $23^{\text {th }}$, 2010) and mature barleys were harvested on June $6^{\text {th }}$, 2010, which is 40 days after heading date. Steam blanching, partial drying and de-hulling process were carried out using a newly developed continuous system. The steam blanching system $(1,200 \mathrm{~W} \times 10,000 \mathrm{~L} \times 1,900 \mathrm{H}$ $\mathrm{mm}$ ) with a capacity of $3,500 \mathrm{~kg} \mathrm{hr}^{-1}$ consists of input, blanching and cooling chamber, blanching process was carried out at $95 \pm 1.5^{\circ} \mathrm{C}$ for $2 \mathrm{~min}$. Drying process was performed below $70^{\circ} \mathrm{C}$ with a system consists of drying chamber $(2.0 \mathrm{~W} \times 2.0 \mathrm{~L} \times 2.5 \mathrm{H} \mathrm{m})$, equipped with a fan $(1.3 \mathrm{H} \times 1.5 \mathrm{~L} \mathrm{~m})$, an exhaust fan $(1.2 \mathrm{H} \times 1.3 \mathrm{~L} \mathrm{~m})$ and a heater $(1.0 \mathrm{~W} \times 0.8 \mathrm{~L} \mathrm{~m})$. After blanching and drying, mature barleys were de-hulled to remove the whole hull and approximately $20 \%$ of bran, and the product was called de-hulled barley. For the following analysis of nutrients, 3 kinds of barley grains were ground by an electric miller (FM-909T, Hanil Co., Ltd., Korea), and screened using a sifter (bore diameter: $0.8 \mathrm{~mm}$ ). The subsamples were stored at $-20^{\circ} \mathrm{C}$.

\section{Color and water, protein, ash, and dietary fibre analysis}

The content of water, protein, ash, and dietary fibre were analyzed according to Helrich (1990). The color of barley was measured as Hunter L* (lightness/darkness), $\mathrm{a}^{*}$ (redness/greenness) and b* (yellowness/blueness) values with a JC801 colorimeter (Color Techno System Corp., Tokyo, Japan).

\section{Amino acids analysis}

High-speed amino acid analyzer (L-8900 A, Hitachi) was used to obtain amino acid profiles of grain protein. Sample was prepared by hydrolysis of $\mathrm{HCl}$ at $105^{\circ} \mathrm{C}$ for $24 \mathrm{~h}$ according to the method slightly modified by Jiang et al. (2013). Hydrolysate was dissolved in distilled water. After centrifuged and filtered, supernatant was used for analysis.

\section{Fatty acid composition analysis}

Analysis was conducted following the method from Zhu et al. (2009). Hewlett-Packard 6890 GC (Agilent Technologies, Little Falls, DE, USA) with a fused-silica capillary column (SP-2560, $100 \mathrm{~m} \times 0.25 \mathrm{~mm}$ i.d., $0.2-\mathrm{mm}$ film thickness, Supelco, Bellefonte, PA, USA) and a flame-ionization detector (at $285^{\circ} \mathrm{C}$ ) was used. The oven was set at $100^{\circ} \mathrm{C}$ and held for $4 \mathrm{~min}$, then increased to $240^{\circ} \mathrm{C}$ at the rate of $3^{\circ} \mathrm{C} / \mathrm{min}$ and held again for 15 min. Helium was used for carrier gas with flow rate of $0.75 \mathrm{~mL} / \mathrm{min}$ in constant mode.

\section{Selected minerals analysis}

The ash from each sample was used for analysis. The contents of $\mathrm{Na}, \mathrm{Ca}, \mathrm{Fe}, \mathrm{K}, \mathrm{P}$ and $\mathrm{Cu}$ were determined using an ICP-AES (Spectro Analytical Instruments, USA) according to methods of Afshar-Mohammadian \& Rahimi-Koldeh (2010).

\section{Vitamin C, B1, B2, B3 and B6 analysis}

Vitamin C (ascorbic acid) was determined by the indophenols titration method (Hewitt and Dickes, 1961). For vitamin $\mathrm{B}_{1}$ (thiamine) and vitamin $\mathrm{B}_{3}$ (niacin) determination, each sample (1 g) was settled to $50 \mathrm{~mL}$ by sodium 1-hexanesulfonate. After $30 \mathrm{~min}$ incubation the upper-layer was filtered. Samples were chromatographically analyzed using a YMC-Pack ODS-AM column (250 mm×4.6 mm, Waters Corporation, Milford, MA, USA) with mobile phase consisted of $5 \mathrm{mM}$ sodium 1-hexanesulfonate and $5 \mathrm{mM}$ sodium 1-hexanesulfonate in $50 \%$ methanol. UV detector was set at $270 \mathrm{~nm}$. For vitamin $\mathrm{B}_{2}$ (riboflavin), samples were chromatographically analyzed using a Capcellapk C18 column (250 mm× $4.6 \mathrm{~mm}, 5 \mu \mathrm{m}$ ) with mobile phase consisted of $10 \mathrm{mM}$ $\mathrm{NaH}_{2} \mathrm{PO}_{4}(\mathrm{pH} 5.5)$ and methanol (75:25, v:v). Vitamin $\mathrm{B}_{2}$ was detected using a fluorescence detector set to $\lambda_{\text {excitation }}$ $=445 \mathrm{~nm}$ and $\lambda_{\text {emission }}=530 \mathrm{~nm}$. For vitamin B6 (pyridoxine), each sample was analyzed by HPLC with $50 \mathrm{mM}$ $\mathrm{NaH}_{2} \mathrm{PO}_{4}(\mathrm{pH} 2.5)$ as elutant. The fluorescence detector was operated at $\lambda_{\text {excitation }}=290 \mathrm{~nm}$ and $\lambda_{\text {emission }}=396 \mathrm{~nm}$.

\section{Vitamin $\mathbf{E}(\alpha-, \gamma$-tocopherol), provitamin $\mathbf{A}$ $(\beta$-carotene) and phytosterols analysis}

Each barley sample (2g) was weighted and 6\% pyrogallol in ethanol $(10 \mathrm{~mL})$ was added as an antioxidant. $5 \alpha$-cholestane $\left(1 \mathrm{mg} \mathrm{mL}^{-1}\right)$ was used as internal standard for phytosterol quantification. After sonication, the mixture was saponified with $60 \% \mathrm{KOH}$ solution at $80^{\circ} \mathrm{C}$ for $1 \mathrm{~h}$. Then, $5-7 \mathrm{~mL}$ of solvent mixture (hexane: ethyl acetate, $85: 15 \mathrm{v}: \mathrm{v})$ was used to extract three times. Beta-carotene was analyzed using a HPLC system with Nova-Pak C18 column ( $4 \mu \mathrm{m}, 3.9 \mathrm{~mm} \times 150 \mathrm{~mm}$, Waters, Milford, Massachusetts, Ireland) and Yonglin UV830 detector set at $450 \mathrm{~nm}$. The elution solvents were A (acetonitrile: dichloromethane: methanol, 70:30:10, v:v:v) and B (acetonitrile: methanol: dichloromethane, 75:25:10) with the following gradient: $0 \%$ A hold $3.5 \mathrm{~min}, 0 \%$ to $100 \%$ A from 3.5 to $18.5 \mathrm{~min}$. Keep for $10 \mathrm{~min}$ and decline to $0 \%$ from 28.5 to $30.0 \mathrm{~min}$. $\alpha$ - and $\gamma$-tocopherol were analyzed using HPLC system with a Chromsep Cartridge, LiChrosorb Diol column $(5 \mu \mathrm{m}, 3 \mathrm{~mm} \times 100 \mathrm{~mm}$, Chromapack, Rartian, NJ, USA) and Yonglin UV830 detector set at $295 \mathrm{~nm}$. The mobile phase was a mixture of hexane fortified with $0.1 \%$ acetic acid (1000:1 v/v). Phytosterols analysis were carried out by M600D (Yonglin, Anyang, Korea) GC equipped with a flame-ionization detector and an Ultra-2 column (5\% diphenyl, 95\% dimethylsiloxane, $30 \mathrm{~m} \times 0.25 \mathrm{~mm}$ i.d., $0.2-\mathrm{mm}$ film thickness, Agilent Technologies, Santa Clara, CA, USA). Nitrogen was used as a carrier gas. Oven temperature was $285^{\circ} \mathrm{C}$, and the detector and injector temperature were 250 and $300^{\circ} \mathrm{C}$, respectively. 


\section{Choline and Betaine}

The analysis was conducted according (Graham et al., 2009) by ${ }^{1} \mathrm{H}$ NMR. The spectra were recorded in $\mathrm{D}_{2} \mathrm{O}$ on a JEOL JNM-AL400 spectrometer, operating at a ${ }^{1} \mathrm{H}$ frequency of $399.65 \mathrm{MHz}$ with a relaxation delay of $3 \mathrm{~s}$, a spectral width of $7992.00 \mathrm{~Hz}$ and a mixing time of $50 \mathrm{~ms}$. The sample temperature was $293 \mathrm{~K}$. The chemical shifts $(\delta)$ were referred to the TSP at $\delta=0 \mathrm{ppm}$.

\section{Statistical analysis}

Each experimental set was compared with one-way analysis of variance (ANOVA) and Least-significant difference (LSD) ( $\mathrm{P} \leq$ 0.05) using SPSS 16.0 (SPSS inc. 2007). All data were expressed as means \pm standard deviations of duplicate measurements.

\section{RESULTS AND DISCUSSION}

\section{Proximate composition and color}

Table 1 shows the proximate composition and color of premature barley, mature barley, and de-hulled barley. Premature barley contained less water than the other two grain-types. Furthermore, the ash content was higher in premature and mature barley compared to hulled bar-

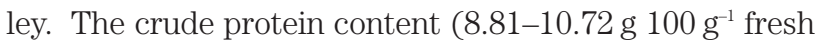
weight (FW), which is equivalent to $10.0-12.95{\mathrm{~g} 100 \mathrm{~g}^{-1}}^{-1}$ dry weight (DW)) of all three barley grains was similar to that previously reported by Baik and Ullrich (2008),

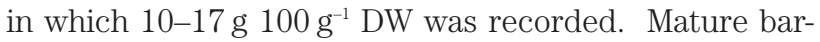

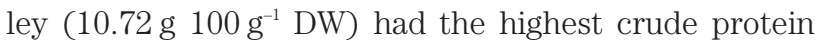
content. The total dietary fiber content ranged from 13

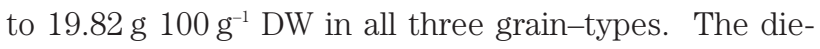
tary fiber content of premature barley was not significantly different to that of de-hulled barley, which may partly be explained by the soft texture of premature barley. There was a significant difference in color among the three barley types. De-hulled barley was much brighter ( $\mathrm{L}^{*}:$ 68.46) than mature and premature barley $(\mathrm{P} \leq 0.05)$. Mature barley was more red (a*: 3.41) and yellow (b*: $32.22)$ in color compared to the other two types $(\mathrm{P} \leq$ $0.05)$.

\section{Amino acid profile}

The amino acid profiles of the three types of grain are shown in Table 2. Even though premature barley contained the lowest amount of crude protein (Table 1), it had a significantly greater total essential amino acid (EAA) content ( $351.75 \mathrm{mg} \mathrm{g}^{-1}$ protein) compared to the other two grain-types $(\mathrm{P} \leq 0.05)$. There was variation in the amounts of EAAs in the three grain-types, with the EAA relative contents (\%) [Level of total EAAs ( $\mathrm{mg} \mathrm{g}^{-1}$ of protein)/sum of all measured amino acids ( $\mathrm{mg} \mathrm{g}^{-1}$ protein) $\times 100$ ] accounting for $34.73-35.98 \%$ of total amino acids. Glutamic acid was the most abundant amino acid among the three barley grains, with the highest content being recorded in premature barley $\left(274.36 \mathrm{mg} \mathrm{g}^{-1}\right.$ protein). Similar values have been obtained in previous studies (Van Wijk et al., 1998; Mariscal-Landín et al., 2005). Table 2 shows that the contents of most amino acids were significantly higher in premature barley compared to mature and de-hulled barley $(\mathrm{P} \leq 0.05)$. In contrast, mature barley had the highest contents of tyrosine, cysteine, and arginine. Lysine is the limiting amino acid in most cereal grains, and in this study, premature barley was found to have the highest lysine content $(41.46 \mathrm{mg}$ $\mathrm{g}^{-1}$ protein, equivalent to $35.53 \mu \mathrm{g} \mathrm{g}^{-1} \mathrm{DW}$ grain). This content is comparable to other whole grains, with $20 \mu \mathrm{g}$ $\mathrm{g}^{-1}$ DW being reported for rye grain, $20 \mu \mathrm{g} \mathrm{g}^{-1} \mathrm{DW}$ for wheat grain, and $18 \mu \mathrm{g} \mathrm{g}^{-1} \mathrm{DW}$ for oat grain (Mustafa et al., 2007). Furthermore, the levels of EAAs in premature, mature, and de-hulled barley were comparable to FAO/WHO (1991) specifications. The level of total EAAs in premature barley (351.75 $\mathrm{mg} \mathrm{g}^{-1}$ protein) exceeded FAO/WHO requirements $\left(328 \mathrm{mg} \mathrm{g}^{-1}\right.$ protein, excludes tryptophan). Thus, premature barley seemed to be superior to mature and de-hulled barley grains regarding total EAA content.

\section{Fatty acid composition}

Table 3 shows the fatty acid contents of the three grain-types. Total fatty acids ranged from 1.50 to $2.94 \mathrm{mg}$ $100 \mathrm{~g}^{-1}$ DW. The major fatty acids of all three analyzed barley grains were palmitic (16:0, $0.41-0.73 \mathrm{mg} 100 \mathrm{~g}^{-1}$ DW), oleic (18:1, 0.17-0.39 mg $\left.100 \mathrm{~g}^{-1} \mathrm{DW}\right)$, and linoleic

Table 1. Proximate composition (g $100 \mathrm{~g}^{-1} \mathrm{DW}$ ) and color of premature, mature and de-hulled barley

\begin{tabular}{|c|c|c|c|}
\hline & Premature barley & Mature barley & De-hulled barley \\
\hline Water content & $10.44 \pm 0.06^{\mathrm{c}}$ & $12.05 \pm 0.01^{\mathrm{a}}$ & $11.36 \pm 0.03^{\mathrm{b}}$ \\
\hline Ash & $1.70 \pm 0.09^{\mathrm{a}}$ & $1.80 \pm 0.02^{\mathrm{a}}$ & $1.00 \pm 0.06^{\mathrm{b}}$ \\
\hline Crude protein (g $100 \mathrm{~g}^{-1} \mathrm{FW}$ ) & $8.81 \pm 0.11^{\mathrm{c}}$ & $10.72 \pm 0.16^{\mathrm{a}}$ & $9.17 \pm 0.04^{\mathrm{b}}$ \\
\hline Total Dietary Fibre & $13.00 \pm 0.06^{\mathrm{b}}$ & $19.82 \pm 0.33^{\mathrm{a}}$ & $14.52 \pm 0.93^{\mathrm{b}}$ \\
\hline \multicolumn{4}{|l|}{ Color } \\
\hline $\mathrm{L}^{*}$ & $49.73 \pm 0.14^{\mathrm{c}}$ & $55.05 \pm 0.67^{\mathrm{b}}$ & $68.46 \pm 0.56^{\mathrm{a}}$ \\
\hline$a^{*}$ & $-3.25 \pm 0.14^{\mathrm{c}}$ & $3.41 \pm 0.18^{\mathrm{a}}$ & $-0.87 \pm 0.63^{\mathrm{b}}$ \\
\hline$b^{*}$ & $25.93 \pm 0.17^{\mathrm{b}}$ & $32.22 \pm 0.84^{\mathrm{a}}$ & $24.59 \pm 4.37^{\mathrm{b}}$ \\
\hline
\end{tabular}

Values are mean \pm SD of duplicate. Means in rows with different letters $(\mathrm{a}-\mathrm{c})$ are significantly different $(P \leq 0.05)$.

$\mathrm{L}^{*}$ : lightness/darkness; $\mathrm{a}^{*}$ : redness/greenness; and b*: yellowness/blueness. 
Table 2. Amino acid profile (mg ${ }^{\mathrm{g}-1}$ protein) of premature, mature and de-hulled barley

\begin{tabular}{lcccc}
\hline \multicolumn{1}{c}{ Amino acid } & Premature barley & Mature barley & De-hulled barley & $\begin{array}{c}\text { FAO/WHO (1991) } \\
\text { requirement pattern* }\end{array}$ \\
\hline Essential amino acid & & & \\
Isoleucine & $36.23 \pm 0.07^{\mathrm{a}}$ & $32.23 \pm 0.32^{\mathrm{c}}$ & $33.85 \pm 0.54^{\mathrm{b}}$ & 28 \\
Leucine & $79.59 \pm 0.19^{\mathrm{a}}$ & $74.68 \pm 0.57^{\mathrm{b}}$ & $72.62 \pm 1.03^{\mathrm{c}}$ & 66 \\
Lysine & $41.46 \pm 0.07^{\mathrm{a}}$ & $38.10 \pm 0.29^{\mathrm{b}}$ & $32.73 \pm 0.36^{\mathrm{c}}$ & 58 \\
Methionine & $15.39 \pm 0.05^{\mathrm{a}}$ & $14.60 \pm 0.07^{\mathrm{b}}$ & $14.05 \pm 0.43^{\mathrm{c}}$ & $25^{* * *}$ \\
Phenylalanine & $49.28 \pm 0.18^{\mathrm{b}}$ & $46.84 \pm 0.3^{\mathrm{c}}$ & $52.12 \pm 0.75^{\mathrm{a}}$ & \\
Threonine & $38.53 \pm 0.06^{\mathrm{a}}$ & $34.61 \pm 0.25^{\mathrm{b}}$ & $34.00 \pm 0.47^{\mathrm{b}}$ & 34 \\
Valine & $52.78 \pm 0.12^{\mathrm{a}}$ & $49.33 \pm 0.53^{\mathrm{b}}$ & $47.46 \pm 0.75^{\mathrm{c}}$ & 35 \\
Histidine & $22.39 \pm 0.15^{\mathrm{a}}$ & $21.17 \pm 0.12^{\mathrm{b}}$ & $20.91 \pm 0.37^{\mathrm{b}}$ & 19 \\
Tyrosine & $15.85 \pm 0.05^{\mathrm{b}}$ & $17.20 \pm 0.34^{\mathrm{a}}$ & $17.02 \pm 0.13^{\mathrm{a}}$ & $63^{* * *}$ \\
Total EAAs & $351.75 \pm 0.53^{\mathrm{a}}$ & $329.56 \pm 2.72^{\mathrm{b}}$ & $323.52 \pm 4.58^{\mathrm{b}}$ & $328^{* * * *}$ \\
Nonessential amino acid & & & \\
Glutamic acid & $274.36 \pm 1.65^{\mathrm{a}}$ & $241.50 \pm 1.18^{\mathrm{c}}$ & $269.50 \pm 3.36^{\mathrm{b}}$ & \\
Proline & $110.41 \pm 0.92^{\mathrm{b}}$ & $102.84 \pm 0.16^{\mathrm{c}}$ & $117.11 \pm 1.75^{\mathrm{a}}$ & \\
Glycine & $44.56 \pm 0.13^{\mathrm{a}}$ & $41.65 \pm 0.38^{\mathrm{b}}$ & $38.27 \pm 0.48^{\mathrm{c}}$ & \\
Alanine & $51.74 \pm 0.07^{\mathrm{a}}$ & $40.99 \pm 0.28^{\mathrm{b}}$ & $36.95 \pm 0.2^{\mathrm{c}}$ & \\
Cystine & $10.08 \pm 0.4^{\mathrm{b}}$ & $11.05 \pm 0.32^{\mathrm{a}}$ & $9.81 \pm 0.29^{\mathrm{b}}$ & \\
Aspartic acid & $61.64 \pm 0.16^{\mathrm{a}}$ & $59.38 \pm 0.46^{\mathrm{b}}$ & $55.24 \pm 0.72^{\mathrm{c}}$ & \\
Arginine & $41.37 \pm 0.21^{\mathrm{b}}$ & $45.44 \pm 0.47^{\mathrm{a}}$ & $40.84 \pm 1.17^{\mathrm{b}}$ & \\
Serine & $46.13 \pm 0.21^{\mathrm{a}}$ & $42.72 \pm 0.24^{\mathrm{b}}$ & $42.19 \pm 0.53^{\mathrm{b}}$ & \\
Total amino acid & $993.43 \pm 3.65^{\mathrm{a}}$ & $915.91 \pm 5.45^{\mathrm{c}}$ & $931.61 \pm 12.77^{\mathrm{b}}$ & \\
\hline
\end{tabular}

Values are mean \pm SD of duplicate. Means in rows with different letters $(\mathrm{a}-\mathrm{c})$ are significantly different $(P \leq 0.05)$.

* The suggest pattern for pre-school child (2-5 years).

** Cystine + methionine.

****Tyrosine + phenylalanine

****Total essential amino acids (mg/g protein) exclude tryptophan.

acid (18:2, 0.82-1.62 mg $\left.100 \mathrm{~g}^{-1} \mathrm{DW}\right)$. These results are similar to those reported by Parsons and Price (1974). Interestingly, premature barley contained the lowest amount of total fatty acids ( $\left.1.5 \mathrm{~g} 100 \mathrm{~g}^{-1} \mathrm{DW}\right)$, whereas mature barley contained the highest amount (2.94 g $100 \mathrm{~g}^{-1}$ DW). Even de-hulled barley contained statistically higher amounts of total fatty acids than premature barley $(\mathrm{P} \leq 0.05)$. The percentages of saturated fatty acid (SFA), monounsaturated fatty acids (MUFA), and polyunsaturated fatty acids (PUFA) were also obtained (Table 3). Premature barley contained the highest amount of PUFA (60.1\%), whereas de-hulled barley contained the highest amount of SFA (28.98\%).

\section{Phytosterols and minerals}

Phytosterols are a group of bioactive plant compounds that cannot be synthesized by humans. These compounds may potentially have beneficial health effects in terms of lowering LDL cholesterol levels (Lampi et al., 2004). In this study, levels of the phytosterols ( $\beta$-sitosterol, campesterol, and stigmasterol) were measured, with total phytosterols representing the sum of these three compounds (Table 4). $\beta$-sitosterol was the most common phytosterol in barleys, as previously found by Ryan et al. (2007). Mature barley had the highest total phytosterol content (61.76 mg $100 \mathrm{~g}^{-1}$ ) among the analyzed grains. The phytosterol content of all three barley types (50.24-61.76 mg $\left.100 \mathrm{~g}^{-1} \mathrm{DW}\right)$ was similar to

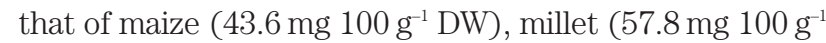
DW), and rye (75.9 mg $100 \mathrm{~g}^{-1} \mathrm{DW}$ ) (Ryan et al., 2007).

The calcium $(\mathrm{Ca})$, iron $(\mathrm{Fe})$, sodium $(\mathrm{Na})$, potassium $(\mathrm{K})$, phosphorus $(\mathrm{P})$, and copper $(\mathrm{Cu})$ contents of all three grain-types were analyzed (Table 4). K and P were the major minerals present in all three barley graintypes, whereas the contents of $\mathrm{Fe}$ and $\mathrm{Cu}$ were low. For example, $\mathrm{K}$ accounted for nearly $62 \%$ of the total mineral content in premature barley, $47.93 \%$ in mature barley, and $48.13 \%$ in de-hulled barley. Overall, premature barley contained significantly more $\mathrm{Na}$ and $\mathrm{K}$ than mature and de-hulled barley ( $\mathrm{P} \leq 0.05)$, while mature barley contained significantly more $\mathrm{P}$ and $\mathrm{Fe}(\mathrm{P} \leq 0.05)$. Similar $\mathrm{Ca}$ and $\mathrm{Cu}$ contents were recorded in all three barley grains.

\section{Vitamins}

The vitamin and $\beta$-carotene contents of the three grains are presented in Fig 1 . Vitamin C $\left(0.93 \mathrm{mg} 100 \mathrm{~g}^{-1}\right.$ DW), vitamin $B_{2}\left(0.10 \mathrm{mg} 100 \mathrm{~g}^{-1} \mathrm{DW}\right)$, and vitamin $\mathrm{B}_{3}$ (2.16 mg $100 \mathrm{~g}^{-1} \mathrm{DW}$ ) levels were higher in premature bar- 
Table 3. Fatty acid composition (mg $\left.100 \mathrm{~g}^{-1} \mathrm{DW}\right)$ and percentage of total fatty acids ofpremature, mature and de-hulled barley

\begin{tabular}{|c|c|c|c|}
\hline Fatty acid & Premature barley & Mature barley & De-hulled barley \\
\hline Myristic acid (14:0) & $\mathrm{ND}$ & $0.01 \pm 0.01^{\mathrm{a}}$ & $0.01 \pm 0.00^{\mathrm{a}}$ \\
\hline Palmitic acid (16:0) & $0.41 \pm 0.01^{\mathrm{c}}$ & $0.73 \pm 0.01^{\mathrm{a}}$ & $0.62 \pm 0.01^{\mathrm{b}}$ \\
\hline Stearic acid (18:0) & $0.02 \pm 0.01^{\mathrm{b}}$ & $0.03 \pm 0.01^{\mathrm{a}}$ & $0.03 \pm 0.01^{\mathrm{a}}$ \\
\hline Oleic acid [18:1(n-9)c] & $0.15 \pm 0.01^{c}$ & $0.36 \pm 0.01^{\mathrm{a}}$ & $0.24 \pm 0.01^{\mathrm{b}}$ \\
\hline Vaccenic acid [18:1(n-7)c] & $0.02 \pm 0.00^{\mathrm{b}}$ & $0.03 \pm 0.00^{\mathrm{a}}$ & $0.02 \pm 0.00^{\mathrm{b}}$ \\
\hline Linoleic acid [18:2(n-6)c] & $0.82 \pm 0.01^{\mathrm{c}}$ & $1.62 \pm 0.03^{\mathrm{a}}$ & $1.20 \pm 0.02^{\mathrm{b}}$ \\
\hline Arachidic acid (20:0) & ND & $0.01 \pm 0.00^{\mathrm{a}}$ & ND \\
\hline Gadoleic acid (20:1) & $0.01 \pm 0.00^{\mathrm{b}}$ & $0.02 \pm 0.01^{\mathrm{a}}$ & $0.02 \pm 0.00^{\mathrm{a}}$ \\
\hline$\alpha$-Linolenic acid [18:3(n-3)] & $0.09 \pm 0.01^{\mathrm{b}}$ & $0.14 \pm 0.01^{\mathrm{a}}$ & $0.14 \pm 0.01^{\mathrm{a}}$ \\
\hline Total FAs & $1.50 \pm 0.01^{c}$ & $2.94 \pm 0.04^{\mathrm{a}}$ & $2.27 \pm 0.03^{\mathrm{b}}$ \\
\hline \multicolumn{4}{|l|}{ Percentage of total FAs (\%) } \\
\hline$\sum \mathrm{SFA}$ & $28.53 \pm 0.14^{\mathrm{b}}$ & $26.29 \pm 0.1^{c}$ & $28.98 \pm 0.04^{\mathrm{a}}$ \\
\hline$\sum$ MUFA & $11.36 \pm 0.2^{\mathrm{c}}$ & $13.9 \pm 0.12^{\mathrm{a}}$ & $12.21 \pm 0.07^{\mathrm{b}}$ \\
\hline$\Sigma$ PUFA & $60.1 \pm 0.06^{\mathrm{a}}$ & $59.82 \pm 0.22^{\mathrm{a}}$ & $58.81 \pm 0.03^{\mathrm{b}}$ \\
\hline
\end{tabular}

Values are mean \pm SD of duplicate. Means in rows with different letters $(\mathrm{a}-\mathrm{c})$ are significantly different $(P \leq 0.05)$.

ND: not detected.

$\sum$ SFA: total saturated fatty acid; $\Sigma$ MUFA: total monounsaturated fatty acids; $\Sigma$ PUFA: total polyunsaturated fatty acids.

Table 4. Contents (mg $100 \mathrm{~g}^{-1} \mathrm{DW}$ ) of phytosterols and selected minerals of premature, mature and dehulled barley

\begin{tabular}{|c|c|c|c|}
\hline & Premature barley & Mature barley & De-hulled barley \\
\hline \multicolumn{4}{|l|}{ Phytosterol } \\
\hline$\beta$-sitosterol & $40.41 \pm 0.51^{\mathrm{b}}$ & $45.65 \pm 4.84^{\mathrm{a}}$ & $45.18 \pm 0.84^{\mathrm{a}}$ \\
\hline stigmasterol & $4.60 \pm 1.37^{\circ}$ & $7.41 \pm 1.80^{\mathrm{a}}$ & $6.91 \pm 1.60^{\mathrm{b}}$ \\
\hline campesterol & $5.24 \pm 0.49^{\mathrm{b}}$ & $8.70 \pm 2.52^{\mathrm{a}}$ & $7.43 \pm 0.33^{\mathrm{a}}$ \\
\hline Total phytosterols & $50.24 \pm 2.37^{\mathrm{b}}$ & $61.76 \pm 8.48^{\mathrm{a}}$ & $59.51 \pm 0.43^{\mathrm{a}}$ \\
\hline \multicolumn{4}{|l|}{ Mineral } \\
\hline $\mathrm{Ca}$ & $41.50 \pm 4.01^{\mathrm{a}}$ & $41.79 \pm 3.58^{\mathrm{a}}$ & $45.93 \pm 0.79^{\mathrm{a}}$ \\
\hline $\mathrm{Fe}$ & $3.14 \pm 0.13^{b}$ & $7.11 \pm 0.12^{\mathrm{a}}$ & $3.42 \pm 0.03^{\mathrm{b}}$ \\
\hline $\mathrm{Na}$ & $19.43 \pm 0.02^{\mathrm{a}}$ & $11.52 \pm 0.06^{\mathrm{b}}$ & $8.54 \pm 0.55^{\mathrm{c}}$ \\
\hline $\mathrm{K}$ & $547.29 \pm 5.30^{\mathrm{a}}$ & $430.52 \pm 0.13^{\mathrm{b}}$ & $247.27 \pm 0.60^{c}$ \\
\hline $\mathrm{P}$ & $279.12 \pm 7.47^{\mathrm{b}}$ & $406.88 \pm 6.57^{\mathrm{a}}$ & $208.35 \pm 2.55^{c}$ \\
\hline $\mathrm{Cu}$ & $0.33 \pm 0.01^{\mathrm{a}}$ & $0.33 \pm 0.01^{\mathrm{a}}$ & $0.24 \pm 0.00^{\mathrm{b}}$ \\
\hline
\end{tabular}

Values are mean \pm SD of duplicate. Means in rows with different letters (a-c) are significantly different $(P \leq 0.05)$.

ley compared to mature and de-hulled barley. Vitamin E is a well-known antioxidant, generating important lipophilic quenchers of reactive oxygen species and lipid radicals (Kamal-Eldin and Appelqvist, 1996). It has been reported that $\alpha$ - and $\gamma$-tocopherol are the major tocopherols in most cereal grains (Falk et al., 2004). In this study, $\gamma$-tocopherol was only found in mature barley (0.21 mg $100 \mathrm{~g}^{-1} \mathrm{DW}$ ), whereas $\alpha$-tocopherol was found in all three barley grains. Significantly higher levels of $\alpha$-tocopherol were recorded in mature barley $(0.85 \pm$ $\left.0.04 \mathrm{mg} 100 \mathrm{~g}^{-1} \mathrm{DW}\right)$ compared to the other two grain types (premature barley: $0.34 \pm 0.02 \mathrm{mg} 100 \mathrm{~g}^{-1} \mathrm{DW}$; dehulled barley: $0.38 \pm 0.15 \mathrm{mg} 100 \mathrm{~g}^{-1} \mathrm{DW} ; \mathrm{P} \leq 0.05$ ). There was no significant difference in $\alpha$-tocopherol content between premature and de-hulled barley $(\mathrm{P}>0.05)$. These results are consistent with those of a previous study by Falk et al. (2004), indicating that tocopherols accumulate in barley grain during development. Of note, $\beta$-carotene $\left(69.79 \pm 1.09 \mu \mathrm{g} 100 \mathrm{~g}^{-1} \mathrm{DW}\right)$ was only found in premature barley. Therefore, premature barley is a rich source of vitamin $\mathrm{C}$ and vitamin $\mathrm{B}_{3}$ compared to mature and de-hulled barley. 


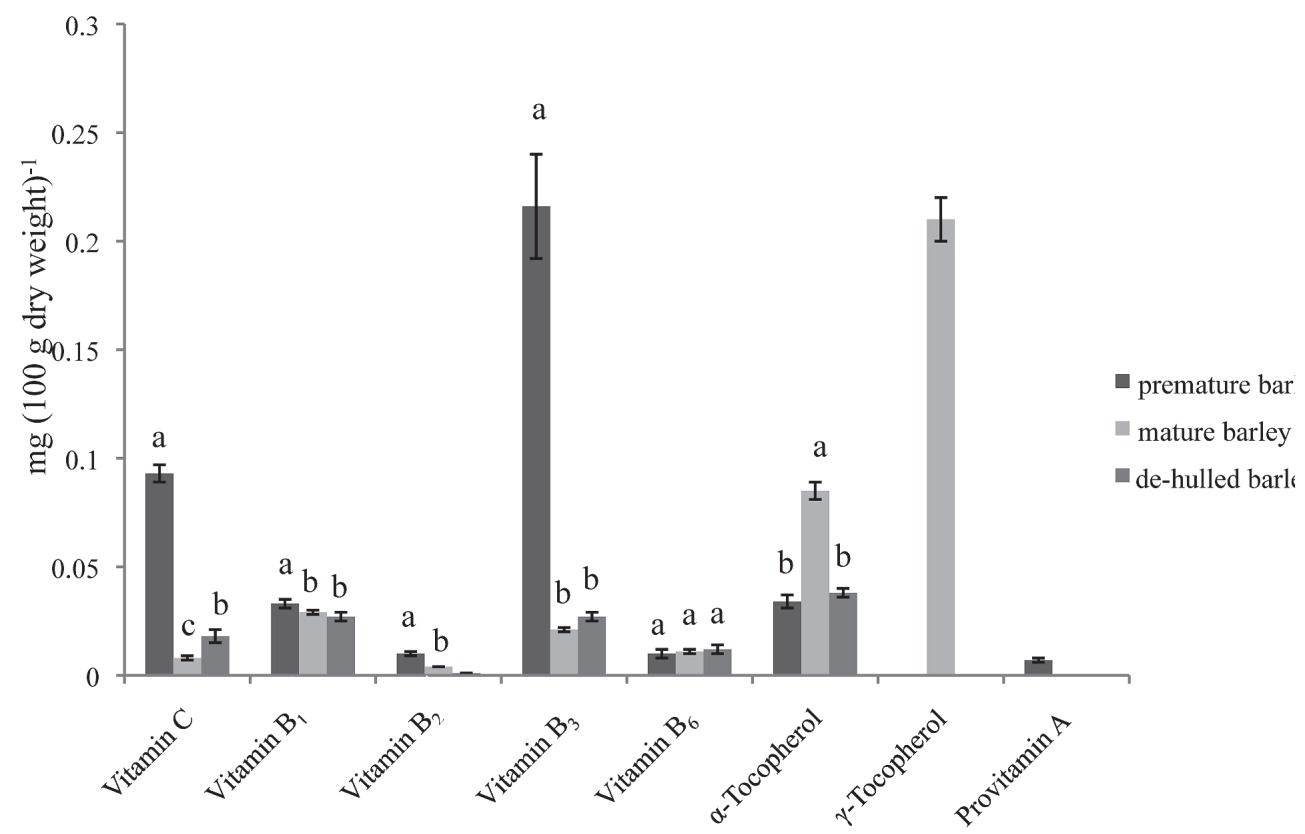

Fig. 1. The vitamins and provitamin contents of premature, mature and de-hulled barley. Different letters (a-c) on top of each column indicates significantly differences $(P \leq 0.05)$.

\section{Betaine and choline}

Betaine (also known as trimethyl glycine or glycine betaine) is useful in the treatment of coronary artery disease (Vos, 2000) and fatty liver disease (Abdelmalek et al., 2001; Cave et al., 2007). Choline is structurally similar to betaine, and may be converted into betaine in vivo or metabolized into acetylcholine and phosphatidylcholine (Zeisel, 2006; Likes et al., 2007). The betaine and choline content of premature, mature, and de-hulled barley was quantified using ${ }^{1} \mathrm{H}$ NMR (Table 5). The highest betaine and choline contents were recorded in mature

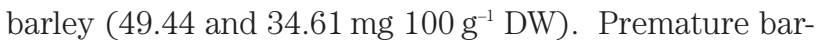
ley (35.04 mg $\left.100 \mathrm{~g}^{-1} \mathrm{DW}\right)$ contained significantly higher amounts of betaine than de-hulled barley $(30.22 \mathrm{mg}$ $\left.100 \mathrm{~g}^{-1} \mathrm{DW}\right)(\mathrm{P} \leq \mathrm{0.05})$. However, de-hulled barley (20.61 mg $100 \mathrm{~g}^{-1} \mathrm{DW}$ ) contained significantly higher levels of choline than premature barley $\left(11.73 \mathrm{mg} 100 \mathrm{~g}^{-1}\right.$ DW) $(\mathrm{P} \leq 0.05)$. Bruce et al. (2010) measured total betaine and free choline in whole-grain barley using LC-MS, we obtained similar results for betaine but $60 \%$

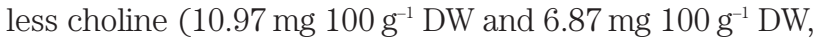
respectively) using ${ }^{1} \mathrm{H}$ NMR. This discrepancy may be due to the difficulty in determining total choline levels,

Table 5. Contents (mg $100 \mathrm{~g}^{-1} \mathrm{DW}$ ) of betaine and choline of premature, mature and de-hulled barley

\begin{tabular}{lccc}
\hline & Premature barley & Mature barley & De-hulled barley \\
\hline Choline & $11.73 \pm 0.47^{\mathrm{c}}$ & $34.61 \pm 1.72^{\mathrm{a}}$ & $20.61 \pm 0.4^{\mathrm{b}}$ \\
Betaine & $35.04 \pm 0.47^{\mathrm{b}}$ & $49.44 \pm 0.25^{\mathrm{a}}$ & $30.22 \pm 0.08^{\mathrm{c}}$ \\
\hline
\end{tabular}

Values are mean \pm SD of duplicate. Means in rows with different letters $(\mathrm{a}-\mathrm{c})$ are significantly different $(P \leq 0.05)$. as this compound has several forms, including choline, glycerophosphocholine, phosphocholine, and phosphatidylcholine, and ${ }^{1} \mathrm{H}$ NMR detects free and conjugated choline in a single peak (Graham et al., 2009). Therefore, the results indicate that a large component of choline in barley grains is present in the conjugated form.

\section{CONCLUSIONS}

The amino acid profile of premature barley is nutritionally better (particularly with respect to lysine and total EAAs) than that of mature and de-hulled barley. Premature barley also has higher contents of vitamins C, $\mathrm{B}_{2}$, and $\mathrm{B}_{3}$ compared to mature and de-hulled barley. Interestingly, $\beta$-carotene was found only in premature barley. In addition, higher $\mathrm{Na}$ and $\mathrm{K}$ levels were recorded in premature barley. These results indicate that premature barley could be a potentially important healthy food grain for human consumption, due to its soft texture, palatability, and beneficial nutritional composition.

\section{ACKNOWLEDGMENTS}

This research was supported by Technology Commercialization Support Program, Ministry for Food, Agriculture, Forestry and Fisheries, Republic of Korea. The authors thank Korea Food Research Institute and Joongang Institute of Life Science for analytical support.

\section{REFERENCES}

Abdelmalek M. F., P. Angulo, R. A. Jorgensen, P. B. Sylvestre and K. D. Lindor 2001 Betaine, a promising new agent for patients with nonalcoholic steatohepatitis: results of a pilot study. Am. J. Gastroenterol. 96: 2711-2717 
Afshar-Mohammadian M, J. Rahimi-Koldeh 2010 The comparison of carbohydrate and mineral changes in three cultivars of kiwifruit of Northern Iran during fruit development. Aust. J. Crop Sci. 4: 49-54

Baik B. K. and S. E. Ullrich 2008 Barley for food: Characteristics, improvement, and renewed interest. J. Cereal Sci. 48: 233242

Behall K. M., D. J. Scholfield and J. Hallfrisch 2004 Diets containing barley significantly reduce lipids in mildly hypercholesterolemic men and women. Am. J. Clin. Nutr. 80: 1185-1193

Bruce S. J., P. A. Guy, S. Rezzi and A. B. Ross 2010 Quantitative measurement of betaine and free choline in plasma, cereals and cereal products by isotope dilution LC-MS/MS. J Agric Food Chem. 58: 2055-2061

Cave M., I. Deaciuc, C. Mendez, Z. Song, S. Joshi-Barve, S. Barve and C. McClain 2007 Nonalcoholic fatty liver disease: predisposing factors and the role of nutrition. J. Nutr. Biochem. 18: 184

Falk J., A. Krahnstöver, T. A. van der Kooij, M. Schlensog and K. Krupinska 2004 Tocopherol and tocotrienol accumulation during development of caryopses from barley (Hordeum vulgare L.). Phytochemistry. 65: 2977-2985

FAO/WHO 1991 Protein Quality Evaluation: Report of the Joint FAO/WHO Expert Consultation, Bethesda, Md., USA 4-8 December 1989, Food and Agriculture Organization of the United Nations

Graham S. F., J. H. Hollis, M. Migaud and R. A. Browne RA 2009 Analysis of betaine and choline contents of aleurone, bran, and flour fractions of wheat (Triticum aestivum L.) using $1 \mathrm{H}$ nuclear magnetic resonance (NMR) spectroscopy. J. Agric. Food Chem. 57: 1948-1951

Helrich, K. 1990 Official Methods of Analysis, 15th edn., Association of Official Analytical Chemists Inc., Arlington

Hewitt E. and G. Dickes 1961 Spectrophotometric measurements on ascorbic acid and their use for the estimation of ascorbic acid and dehydroascorbic acid in plant tissues. Biochem. J. 78: 384

Huth M., G. Dongowski, E. Gebhardt and W. Flamme 2000 Functional properties of dietary fibre enriched extrudates from barley. J. Cereal. Sci. 32: 115-128

Jiang X. L., Z. Y. Deng, Z. G. Ru, P. Wu and J. C. Tian 2013 Quantitative trait loci controlling amino acid contents in wheat (Triticum aestivum L.). Aust. J. Crop Sci. 7: 820-829

Kamal-Eldin A., L- $\AA$. Appelqvist 1996 The chemistry and antioxidant properties of tocopherols and tocotrienols. Lipids. 31: $671-701$
Knutsen S. and A. Holtekjølen 2007 Preparation and analysis of dietary fibre constituents in whole grain from hulled and hullless barley. Food Chem. 102: 707-715

Lampi A-M., R. A. Moreau, V. Piironen and K. B. Hicks 2004 Pearling barley and rye to produce phytosterol-rich fractions. Lipids. 39: 783-787

Likes R., R. L. Madl, S. H. Zeisel and S. A. Craig 2007 The betaine and choline content of a whole wheat flour compared to other mill streams. J. Cereal Sci. 46: 93

Mariscal-Landín G., J. Rodríguez and T. Reis de Souza 2005 Evaluation of hulless barley as feed ingredient in growing-finishing pigs diets: amino acid ileal digestibility. Anim. Feed Sci. Technol. 120: 169-176

Mustafa A., P. Åman, R. Andersson and A. Kamal-Eldin 2007 Analysis of free amino acids in cereal products. Food Chem. 105: $317-324$

Panfili G., A. Fratianni, T. D. Criscio and E. Marconi 2008 Tocol and $\beta$-glucan levels in barley varieties and in pearling by-products. Food Chem. 107: 84-91

Parsons J. G. and P. B. Price 1974 Search for barley (Hordeum vulgare L.) with higher lipid content. Lipids. 9: 804-808

Petti S. and C. Scully 2009 Polyphenols, oral health and disease: a review. J. Dent. 37: 413-423

Ryan E., K. Galvin, T. O'Connor, A. Maguire and N. O'Brien 2007 Phytosterol, squalene, tocopherol content and fatty acid profile of selected seeds, grains, and legumes. Plant Foods Hum. Nutr. 62: 85-91

SPSS 2007 SPSS Statistics, Release 16.01. SPSS Inc., Chicago, IL USA.

Van Wijk H., P. Moughan, S. Hodgkinson, P. Jansen and G. Pearson 1998 Variation in apparent and true ileal amino acid digestibility in barley using a rat model. Anim. Feed Sci. Technol. 76: $9-22$

Vos E. 2000 Whole grains and coronary heart disease. Am. J. Clin. Nutr. 71: 1009-1009

Yang D., J. A. Shin, L. J. Gan, X. M. Zhu, S. T. Hong, C. K. Sung, J. W. Cho, J. H. Ku and K. T. Lee 2012 Comparison of nutritional compounds in premature green and mature yellow whole wheat in Korea. Cereal Chem. 89: 284-289

Zeisel S. H. 2006 Choline: critical role during fetal development and dietary requirements in adults. Annu. Rev. Nutr. 26: 229

Zhu X. M., M. A. Alim, J. N. Hu, A. Prakash, J. H. Lee and K. T. Lee 2009 Lipase-catalyzed production of solid fat containing conjugated linoleic acid in binary models. Food Sci. Biotechnol. 18: $803-807$ 